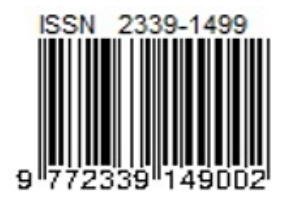

\title{
Pengaruh Shift Kerja Terhadap Kelelahan dan Performansi Pengendali Kereta Api Indonesia
}

\author{
Lauditta Irianti \\ Fakultas Teknologi Industri, Jurusan Teknik Industri, Institut Teknologi Nasional \\ Jl. PHH Mustofa No 23, Bandung 40124 \\ Email: lauditta.irianti@gmail.com
}

\begin{abstract}
The purpose of this study is to evaluate the effect of shift work on level of fatigue and performance of railway controller. Seventeen participants are the railway controller of Bandung Station. Fatigue was measured using subjective questionaire Swedish Occupational Fatigue Inventory (SOFI) and performance was measured using Psychomotor Vigilance Task based on reaction time. Friedman test and Bonferonni-Dunn test were used to process data. Statistical analysis indicates there was significant difference level of fatigue and human performance between shift work. Fatigue occurs at sleepiness, phsysical discomfort and lack of motivation dimensions, while performance occurs at mean 1/RT, fastest $1 / R T$ and slowest $1 / R T(P<0,10) . \%$. The highest fatigue and the worst performance occurs after night shift. After night shift, the level of fatigue increased about $37 \%$ to $162 \%$, meanwhile performance were decreased about $3 \%$ to $11 \%$. Although there were significant difference of level fatigue, the average scores are below 1 (score $0-7$ ). This result indicates that the fatigue of controllers are very low. Although maybe is not really necessary to redesign shift work system, but working hours on each shift still need to be concerned.
\end{abstract}

Keywords: controller, fatigue, train, control, performance

\begin{abstract}
Abstrak
Penelitian ini bertujuan untuk mengevaluasi pengaruh shift kerja terhadap tingkat kelelahan dan performansi pengendali kereta api. Partisipan merupakan 17 petugas pengendali kereta api stasiun besar kelas A Daerah Operasi (DAOP) II Bandung. Alat ukur yang digunakan adalah kuesioner Swedish Occupational Fatigue Inventory (SOFI) untuk mengukur kelelahan dan Psychomotor Vigilance Task dengan waktu reaksi untuk mengukur performansi. Pengolahan data dilakukan dengan uji statistika Friedman dan dilanjutkan dengan uji Post Hoc Bonferonni-Dunn. Hasil penelitian ini menunjukkan bahwa shift kerja signifikan mempengaruhi tingkat kelelahan dan performansi pengendali kereta api. Kelelahan signifikan terjadi pada tingkat kantuk (sleepiness), ketidaknyamanan fisik (physical discomfort) dan penurunan motivasi (lack of motivation) sedangkan pada performansi pada parameter mean 1/RT, fastest 10\% 1/RT dan slowest 10\% 1/RT $(P<0,10)$. Tingkat kelelahan tertinggi dan performansi terburuk terjadi setelah shift malam. Tingkat kelelahan setelah shift malam meningkat sekitar 37\%-162\% sedangkan performansi menurun sekitar 3\%-11\%. Meskipun tingkat kelelahan antar shift berbeda secara signifikan, namun nilai yang dihasilkan sangat kecil, hal ini menunjukkan bahwa kelelahan yang dirasa sangat rendah. Berdasarkan hasil penelitian ini, tindakan perbaikan terhadap sistem shift kerja tidak terlalu diperlukan, namun jam kerja masing-masing shift masih perlu mendapat perhatian.
\end{abstract}

\section{Kata kunci: controller, kelelahan, kereta Api, pengendali, performansi}

\section{Pendahuluan}

Statistik menunjukkan bahwa kecelakaan kereta api sejak tahun 2010 hingga 2015 ratarata mengalami peningkatan sekitar $17 \%$ per tahun (Kementerian perhubungan, 2016). Pada tahun 2012, kecelakaan menurun sekitar 44\% jika dibandingkan dengan tahun 2011, namun pada akhirnya terus meningkat hingga tahun 2015. Penyebab kecelakaan kereta api terdiri dari lima, yaitu sarana, prasarana, sumber daya 
manusia, eksternal dan alam. Statistik menunjukkan bahwa faktor alam menempati peringkat pertama sebagai penyebab kecelakaan kereta api, yaitu sekitar $26 \%$ (Kementerian perhubungan, 2016) dimana alam merupakan faktor yang cukup sulit untuk dikendalikan. Peringkat kedua sebagai faktor penyebab kecelakaan kereta api adalah sumber daya manusia (sekitar 24\%).

Dalam operasionalnya, PT. Kereta Api Indonesia membutuhkan sumber daya manusia yang sangat banyak. Terdapat tiga divisi utama yang berperan penting dalam Operasional perjalanan kereta api dimana salah satunya adalah divisi pengendali kereta api. Pengendali adalah bagian yang bertugas untuk mengawasi perjalanan kereta api baik dalam satu daerah operasi maupun dalam satu stasiun. Selain itu pengendali bertugas dalam mengawasi dan menentukan lintasan mana yang akan dilalui oleh kereta, menentukan penambahan atau pengurangan perjalan kereta api serta menentukan pembatalan perjalanan (Irianti, Geovania \& Iridiastadi, 2015).

Perjalanan kereta api berlangsung selama 21 jam dalam sehari yaitu dari pukul 03.00 00.00 sehingga petugas pengendali diwajibkan bekerja dalam sistem shift yang terdiri dari shift pagi, siang dan malam. Shift pagi berawal dari pukul 08.00 - 14.00, shift siang berawal dari pukul 14.00 - 20.00 dan shift malam berawal dari pukul $20.00-08.00$. Pola shift kerja pada pengendali kereta api adalah 2-2-1-2 (2 pagi, 2 siang, 1 malam, 2 libur). Petugas pengendali dituntut untuk waspada, konsentrasi, dan cepat dalam memberikan keputusan. Penelitian sebelumnya mengenai pengendali kereta api menunjukkan bahwa beban kerja pengendali secara signifikan mempengaruhi tingkat kelelahan (Dorrian, Baulk \& Dawson, 2011), tingkat kantuk yang diakibatkan oleh shift malam (Cotrim, Carvalhais, Neto, Teles \& Noriega \& Rebelo, 2017) serta mengakibatkan gangguan kognitif (Elfering, Grebner \& Haller, 2012).

Performansi yang tinggi, khususnya performansi kognitif, merupakan kewajiban yang dimiliki oleh para petugas pengendali karena hal tersebut sangat berkaitan dengan kelancaran dan keselamatan perjalanan kereta api. Salah satu faktor yang mempengaruhi performansi kerja manusia adalah karateristik pekerjaan (Bridger, 2008) dimana salah satu ruang lingkupnya adalah shift kerja. Shift kerja adalah jadwal pekerjaan di luar jam normal dengan sistem pertukaran atau pergantian antara satu individu atau grup dengan individu atau grup lainnya (Goswani, Jena, \& Mohapatra, 2012 ; Health and Safety Executiver, 2006).

Penelitian sebelumnya menunjukkan beberapa dampak shift kerja yaitu mempengaruhi tingkat kantuk (Gerber, Hartmann, Brand, Trachsler dan Puhse, 2010; Jay, Dawson, Ferguson \& Lamond, 2008 ; Wilkinson, Allison, Feeney \& Zaminska, 2007 ; Ashberg, 1998 ), tingkat kelelahan (Dorrian, Baulk \& Dawson, 2011; Grandjean, Wotzka, Schaad \& Gilgen, 2007; Ashberg, 2000 ), gangguan kognitif (Titova, Lindberg, Elmstahl, Lind \& Schioth, 2016 ; Ozdemir, Selvi, Ozkol, Aydin \& Tuluce, 2013), gangguan konsentrasi dalam bekerja (Gerber, Hartmann, Brand, Trachsler \& Puhse, 2010) dimana pada akhirnya berdampak pada performansi kerja (Coffey, Skipper \& Jung, 2006). Pekerja yang bekerja dengan sistem shift kerja memungkinkan untuk mengalami kurang tidur akibat dari shift malam. Penelitian sebelumnya menunjukkan bahwa kurang tidur berdampak pada menurunnya performansi yang membutuhkan perhatian (Tucker, Whitney, Balenky, Hinson \& Van Dongen, 2010), dan menganggu kecepatan reaksi (Yogi \& Hirkarni, 2016 ).

Health and Safety Executiver (2006) menggambarkan hubungan antara desain pekerjaan terhadap performansi kerja dan menjelaskan bahwa salah satu faktor desain pekerjaan adalah shift kerja, dimana hal tersebut dapat berpengaruh terhadap tingkat kelelahan manusia dan pada akhirnya mempengaruhi performansi manusia. Kelelahan adalah perasaan abnormal berupa letih, lesu, menurunnya kewaspadaan dan lainnya (Ummul \& Kameshwara, 2012) yang menimbulkan keinginan untuk beristirahat (Williamson, Lombardi, Folkard, Stuuts, Courtney, 2009). Kelelahan telah diidentifikasikan sebagai faktor yang berkontribusi pada terjadinya kecelakaan, luka bahkan kematian dimana implikasinya adalah seseorang yang lelah menghasilkan performansi, kinerja dan keselamatan yang rendah (Wilkinson, Allison, Feeney \& Zaminska, 2007; Barbey, Reeves, Arnulf \& Holmes, 2007). Kelelahan pada lingkup pekerjaan kereta api 
merupakan suatu isu penting dalam keselamatan kerja (Harma, 2002).

Performansi manusia adalah pemenuhan tugas yang dilakukan oleh satu orang atau grup kerja (Gawron, 2008). Waktu reaksi merupakan salah satu parameter dalam mengukur performansi kerja (Gawron, 2008). Waktu reaksi adalah kecepatan manusia dalam merespon suatu rangsangan (stimulus). Salah satu pengujian waktu reaksi adalah dengan uji Psychomotor Vigilance Task (PVT). PVT adalah uji kewaspadaan untuk jenis pekerjaan yang membutuhkan perhatian khusus, yang bebas dari efek pembelajaran, dan sensitif terhadap efek kurang tidur, patologi tidur dan fase jam biologis (Johns, 2009 ; Dorria dkk., 2006 dalam Gunzelman, Gross, Gluck \& Dinges, 2009).

Performansi kerja paling buruk terjadi saat bekerja terlalu malam hingga pagi dan performansi terbaik terjadi saat bekerja dari pagi hingga sore (Spencer, 1987 dalam Bridger, 2008). Performansi yang buruk dapat berisiko dalam terjadinya kecelakaan kerja. Bagi pekerja saat shift pagi, risiko kecelakaan kerja terjadi setelah pukul 13.00. Bagi pekerja shift siang risiko kecelakaan kerja terjadi setelah pukul 21.00 dan bagi pekerja shift malam risiko kecelakaan kerja terjadi setelah pukul 05.00 (Hanecke dkk., 1998 dalam Bridger, 2008).

Penelitian mengenai pengendali kereta api di Indonesia masih dapat dikatakan minim. Penelitian mengenai shift kerja untuk pegawai kereta api di Indonesia dilakukan terhadap pekerja bagian daily check (Pratiwi, 2016) dan penjaga perlintasan (Muhammad, 2009). Penelitian mengenai pengendali kereta api meliputi pengaruh beban kerja mental dan kelelahan terhadap kesalahan operator (Nurussakinah, Puspitasari \& Rumita, 2014). Penelitian mengenai shift kerja pada pengendali telah dilakukan namun melihat pengaruh terhadap stres kerja (Irianti, Geovania \& Iridiastadi, 2015). Tujuan dari penelitian ini adalah untuk mengevaluasi hubungan antara shift kerja terhadap kelelahan dan performansi pada pengendali kereta api Indonesia.

\section{Partisipan}

\section{Metodologi Penelitian}

Partisipan pada penelitian ini adalah seluruh petugas pengendali kereta Daerah Operasi 2 Stasiun Bandung berjenis kelamin pria. Pada awal penelitian total partisipan adalah 21 orang, namun pada saat penelitian berlangsung, 4 orang di rotasi oleh pihak perusahaan ke divisi atau kota lain, sehingga total partisipan hingga akhir adalah 17 orang. Data demografi dapat dilihat pada Tabel 1

Tabel 1. Data Demografi Partisipan

\begin{tabular}{|l|c|}
\hline \multicolumn{1}{|c|}{ Demografi } & $\begin{array}{c}\text { Rata-rata } \pm \\
\text { St.dev }\end{array}$ \\
\hline Umur (tahun) & $36 \pm 6,69$ \\
\hline Lama tidur semalam (Jam) & $6,51 \pm 1,28$ \\
\hline $\begin{array}{l}\text { Lama perjalanan ke tempat kerja- } \\
\text { Lancar (menit) }\end{array}$ & $50,88 \pm 53,36$ \\
\hline $\begin{array}{l}\text { Lama perjalanan ke tempat kerja- } \\
\text { macet (menit) }\end{array}$ & $62,65 \pm 36,15$ \\
\hline $\begin{array}{l}\text { Lama bekerja sebagai } \\
\text { PK/PPKA(bulan) }\end{array}$ & $9,06 \pm 8$ \\
\hline
\end{tabular}

Seluruh partisipan tidak memiliki sejarah penyakit fisik maupun mental. Sistem perusahaan mewajibkan setiap karyawan untuk mengalami rotasi pekerjaan yang dirasa sesuai dengan kapabilitas masing-masing sehingga tidak terlepas kemungkinan bahwa para karyawan telah bekerja sangat lama di PT.KAI namun baru beberapa saat sebagai pengendali.

\section{Alat Ukur}

Alat ukur yang digunakan dalam mengukur kelelahan adalah kuesioner Swedish Occupational Fatigue Inventory (SOFI) dan pengukuran performansi dengan waktu reaksi. SOFI adalah pengukuran kelelahan secara subjektif yang dikembangkan oleh Ashberg (1998) yang terdiri dari lima dimensi yaitu : (1) Lack of energy (penurunan energi) ; (2) Physical exertion (ketidaknyamanan pada fisik secara keseluruhan) ; (3) Physical Discomfort (ketidaknyamanan pada beberapa bagian fisik tubuh tertentu) ; (4) Lack of motivation (penurunan motivasi) ; (5) Sleepiness (kantuk). Masing-masing dimensi terdiri dari empat faktor. Kuesioner SOFI terdiri dari tujuh skala dimana skala 0 berarti "tidak merasa sama sekali" hingga skala 6 yaitu "merasa sangat tinggi" (Ashberg, 1998 ; Ashberg, 2000 ; Johansson, Ytterberg, Back, Holmqvist \& Koch, 2008) Kuesioner SOFI diterjemahkan ke dalam bahasa Indonesia atas bantuan ahli bahasa. SOFI dibuat dalam tiga versi untuk masingmasing shift, perbedaan tersebut hanya dari urutan pernyataan. Hal ini dilakukan untuk meminimisasi memory effect (efek ingatan) pada responden (Leung, Chan \& He,v 2004). 
Pengukuran waktu reaksi menggunakan alat ukur software Reaction Times V4.03. Partisipan diminat untuk memperhatikan layar komputer dan menekan tombol spasi pada keyboard saat stimulus muncul. Stimulus yang diberikan merupakan stimulus visual berupa persegi panjang berukuran $5,687 \times 3,254 \mathrm{~cm}$ berwarna merah dengan latar belakang berwarna hijau. Stimulus dimunculkan dengan posisi random. Interval waktu antar stimulus adalah 3-7 detik (Blatter, Graw, Munch, Knoblauch, Justice \& Cajochen, 2006 ; Graw, Krauchi, Knoblauch, Wirz-Justice \& Cajochen, 2004). Pengukuran dilakukan selama 5 menit (Loh, Lamond, Dorrian, Roach, \& Dawsn, 2004 ; Graw, Krauchi, Knoblauch, Wirz-Justice \& Cajochen, 2004). Terdapat empat variabel pengukuran yang diamati (Basner, Mollicone \& Dinges, 2011 ; Basner dan Dinges, 2011; Loh, Lamond, Dorrian, Roach, \& Dawsn, 2004 ; Stoohs, Phillip, Andries, Finlayson \& Guilleminault, 2009; Blatter, Graw, Munch, Knoblauch, Justice \& Cajochen, 2006) yaitu: (1) mean 1/RT; (2) slowest 10\% 1/RT; (3) fastest 10\% 1/RT ; (4) number of lapses.

\section{Prosedur Penelitian}

Penelitian dilakukan langsung di lapangan di tempat kerja. Setiap partisipan melakukan latihan penggunaan alat satu minggu sebelum eksperimen dilakukan (Kaida, Takahashi, Akestedt, Nakata, Otsyka, Haratani \& Fukasawa, 2006) yang bertujuan menghindari hasil pengukuran yang bias yang disebabkan oleh faktor pembelajaran alat.

Pengambilan data dilakukan baik pada shift pagi, shift siang dan shift malam untuk masingmasing partisipan. Dalam mengukur kelelahan dengan menggunakan kuesioner SOFI dilakukan satu kali pada setiap shift di akhir setelah bekerja sedangkan pengukuran waktu reaksi data diambil dua kali pada setiap shift, yaitu saat sebelum bekerja dan tepat setelah bekerja. Setiap partisipan mengalami semua perlakuan sehingga penelitian ini merupakan eksperimen within -subject.

\section{Statistika}

Pengolahan data dilakukan menggunakan software SPSS Statistic v20. Uji statistik yang digunakan adalah Friedman untuk menguji signifikansi pengaruh shift kerja terhadap kelelahan dan waktu reaksi. Penggunaan uji Friedman dilakukan berdasarkan pertimbangan bahwa jumlah sampel yang digunakan kecil. Derajat kepercayaan (a) yang digunakan adalah $10 \%$. Jika hasil pengujian menunjukkan bahwa shift kerja signifikan mempengaruhi kelelahan dan waktu reaksi, maka selanjutnya dilakukan uji Bonferonni-Dunn Post Hoc (Demsar 2006 ; Newson 2006) untuk mengetahui shift mana yang paling mempengaruhi waktu reaksi. Derajat kepercayaaan untuk uji Bonferonni-Dunn Post Hoc menjadi 0,333 ( $\alpha / \mathrm{k})$.

\section{Hasil dan Pembahasan}

Hasil pengukuran SOFI akan dirata-ratakan untuk seluruh partisipan sedangkan hasil pengukuran untuk waktu reaksi sebelum dan setelah bekerja pada setiap shift akan dirataratakan sehingga satu shift hanya memiliki satu nilai SOFI dan waktu reaksi. Hasil pengukuran SOFI dan waktu reaksi dapat dilihat pada Tabel 2

Tabel 2 menunjukkan bahwa tingkat kantuk (sleepinees) tertinggi terjadi pada saat shift malam. Selain itu, data menunjukkan bahwa saat shift malam pekerja merasakan ketidaknyamanan pada beberapa bagian fisik tubuh tertentu (physical discomfort) serta penurunan energi (lack of energy) tertinggi. Berbeda dengan ketiga dimensi tersebut, data menunjukkan bahwa pekerja mengalami penurunan motivasi (lack of motivation) serta ketidaknyamanan pada fisik secara keseluruhan (physical exertion) tertinggi pada saat shift siang. Berdasarkan Tabel 2 diperoleh bahwa shift malam menghasilkan nilai terendah untuk pa rameter mean 1/RT, shortest $10 \%$ 1/RT dan longest 10\% 1/RT. Semakin kecil parameter 1/RT menunjukkan bahwa waktu reaksi semakin melambat. Tabel 2 pun menunjukkan shift malam menghasilkan number of lapses yang paling tinggi. Pola hasil pengukuran waktu SOFI dan waktu reaksi masing-masing partisipan pada setiap shift dapat dilihat pada Gambar 1 dan Gambar 2

Gambar 1 menunjukkan pola hasil pengukuran SOFI pada setiap shift untuk masing-masing partisipan. Gambar 1a,1b dan 1c menunjukkan bahwa nilai yang dihasilkan pada dimensi physical discomfort, sleepiness dan lack of motivation sebagian besar berada pada kisaran 0-1. Saat shift pagi hanya sekitar $6 \%$ dan saat shift malam hanya sekitar $12 \%$ yang merasakan physical discomfort di atas skala 1. 
Dimensi sleepiness menghasilkan proporsi yang sedikit berbeda dengan physical discomfort. Saat shift pagi dan siang sekitar Tabel 2. Hasil pengukuran waktu reaksi dan SOFI
$12 \%$ sedangkan saat shift malam sekitar $41 \%$ yang menghasilkan nilai sleepiness di atas skala 1.

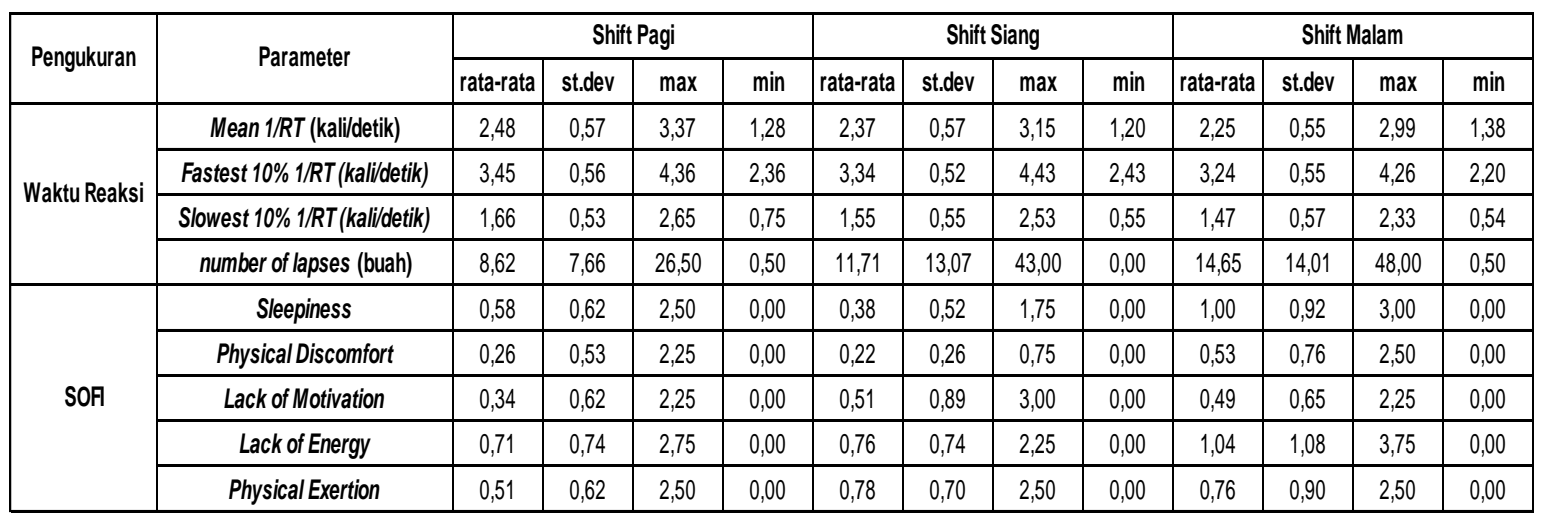
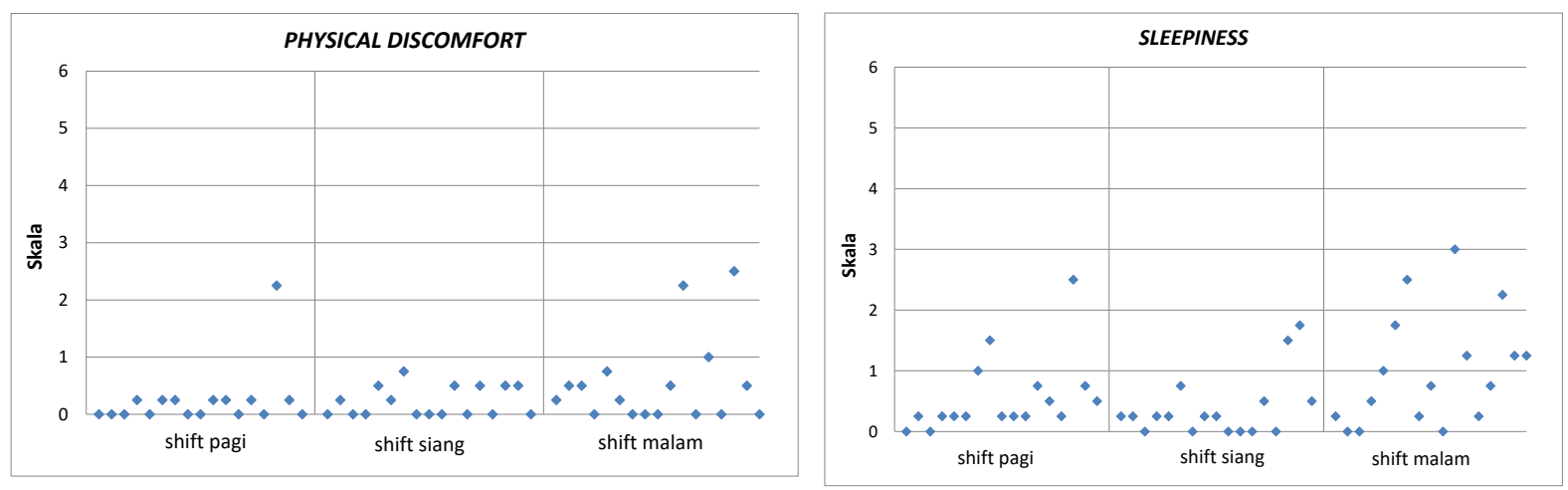

(a)

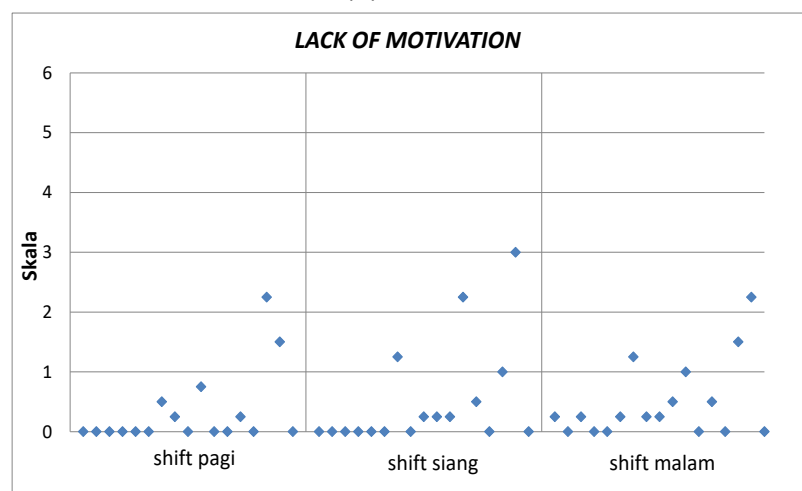

(b)

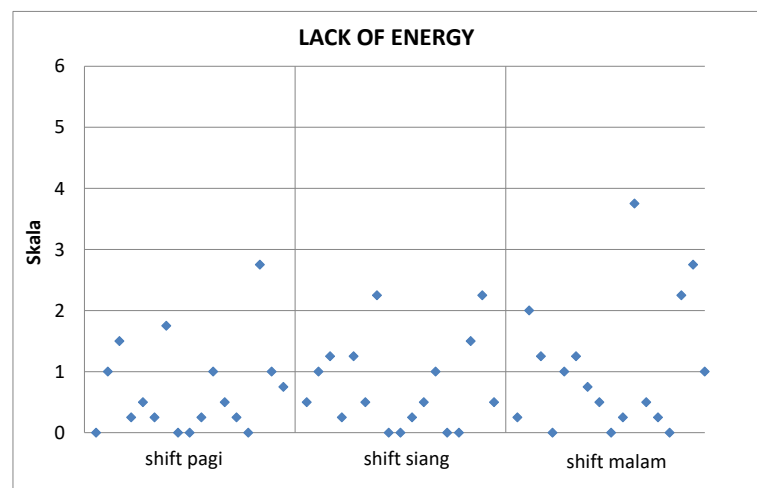

(c)

(d)

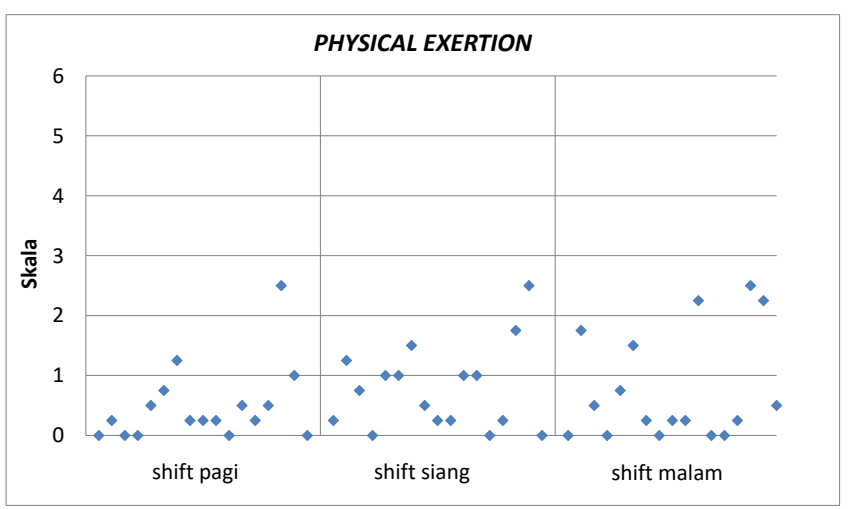


(e)

Gambar 1. Pola pengukuran SOFI pada setiap dimensi

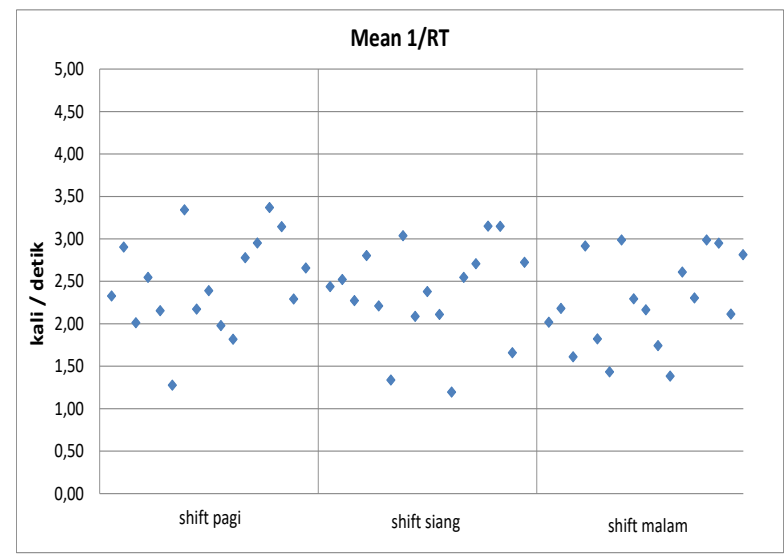

(a)

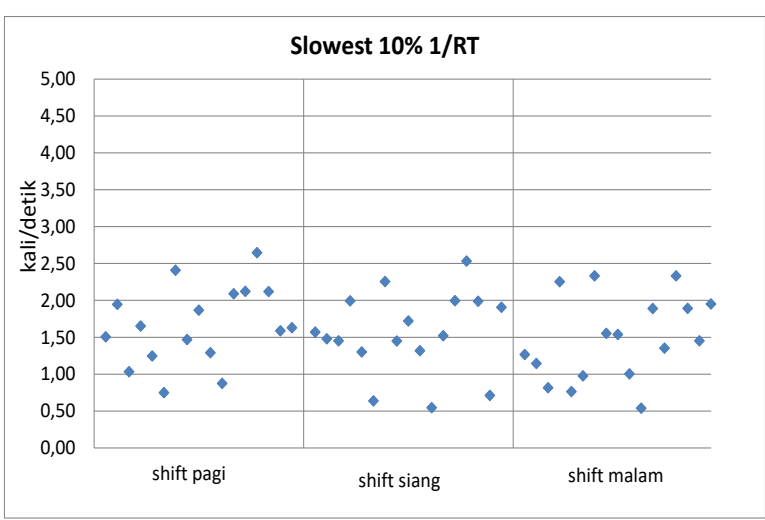

(c)

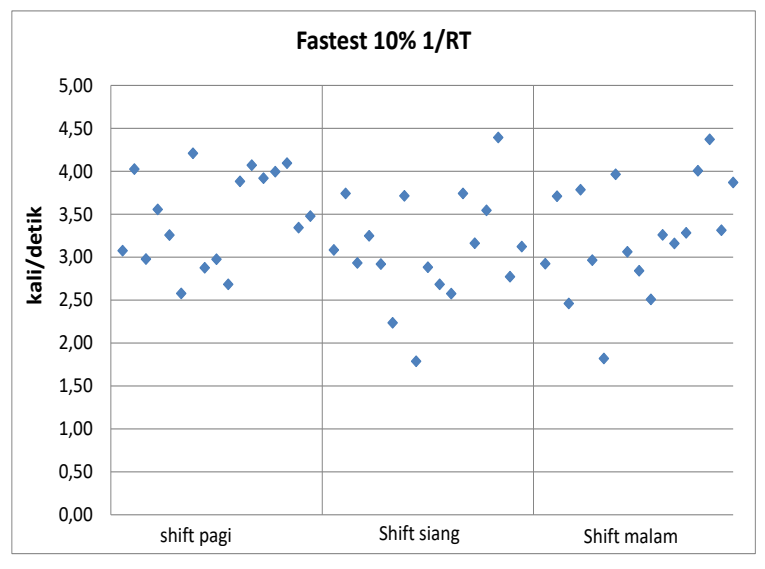

(b)

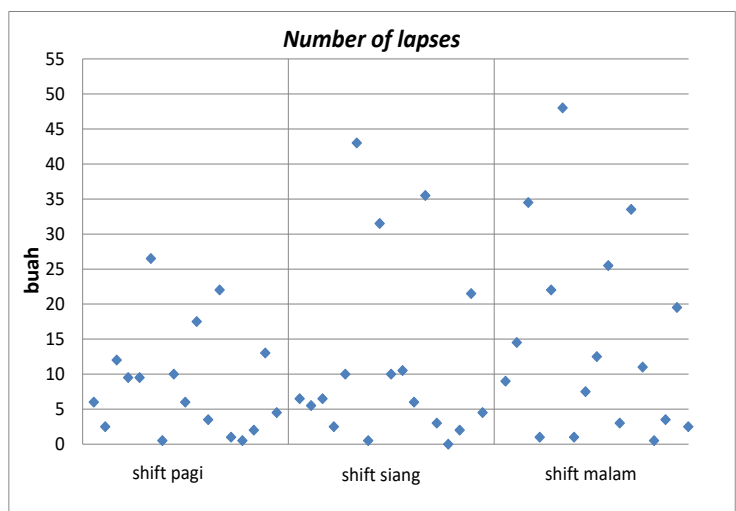

(d)

Gambar 2. Pola pengukuran waktu reaksi pada setiap parameter

Terlihat bahwa pola sleepiness saat shift malam lebih menyebar. Pada dimensi lack of motivation, saat shift pagi sekitar $12 \%$ sedangkan saat shift siang dan malam sekitar $18 \%$ yang menghasilkan nilai di atas skala 1 .

Gambar 1d dan 1e menunjukkan bahwa nilai dimensi lack of energy dan physical exertion memiliki pola yang sangat bervariasi.

Gambar 2.a menunjukkan pola penyebaran parameter mean 1/RT dimana terlihat bahwa sebagian besar (sekitar $71 \%$ ) dari keseluruhan shift nilai yang dihasilkan berada pada nilai 2-3 1/RT. Gambar 2b menunjukkan pola penyebaran parameter fastest 10\% 1/RT dimana sebagian besar (sekitar 55\%) dari keseluruhan shift menghasilkan nilai di antara 3-4 1/RT . Gambar 2c menunjukan bahwa sebagian besar (sekitar 63\%) dari keseluruhan shift menghasilkan nilai di antara 1-2 pada parameter slowest 10\% 1/RT. Gambar 2d 84 menunjukkan bahwa pola penyebaran parameter number of lapses pada keseluruhan shift sebagian besar (sekitar 63\%) berada pada rentang $0-10$.

Perhitungan statistika Friedman dan Bonferonni test dilakukan untuk melihat signifikansi pengaruh antara shift kerja terhadap pengukuran yang dapat dilihat pada Tabel 3. Berdasarkan Tabel 3, Shift kerja secara signifikan mempengaruhi kelelahan dan performansi manusia. Shift kerja mempengaruhi kelelahan pada dimensi SOFI, yaitu sleepiness, physical discomfort dan lack of motivation, sedangkan shift kerja mempengaruhi performansi pada parameter waktu reaksi fastest 10\% 1/RT, slowest 10\% 1/RT dan number of lapses. Berdasarkan hasil bonferonni-test terhadap parameter-parameter yang terbukti signifikan, menunjukkan bahwa sebagian besar shift malam yang paling 
mempengaruhi hasil pengukuran, terutama jika dibandingkan dengan shift pagi. Statistik menunjukkan bahwa hasil pengukuran antara shift malam dan siang tidak terlalu signifikan berbeda. Namun, parameter SOFI sleepiness menunjukkan hal yang berbeda, yaitu bahwa shift malam merupakan yang paling mempengaruhi tingkat kantuk jika dibandingkan kedua shift lainnya. Hal ini menunjukkan indikasi yang sama pada penelitian Ashberg (2000) bahwa kantuk paling signifikan terjadi setelah shift malam.

Tabel 3. Perhitungan statistika seluruh pengukuran

\begin{tabular}{|c|c|l|l|}
\hline Pengukuran & Parameter & Friedman test & Bonferroni-Dunn test \\
\hline \multirow{4}{*}{ Waktu Reaksi } & Mean 1/RT (kali/detik) & $P>0.10$ & - \\
\cline { 2 - 4 } & Fastest 10\% 1/RT (kali/detik) & $P<0.10$ & malam terhadap pagi $(\mathrm{P}<0,033)$ \\
\cline { 2 - 4 } & Slowest 10\% 1/RT (kali/detik) & $P<0.10$ & tidak ada perbedaan yang signifikan \\
\cline { 2 - 4 } & number of lapses (buah) & $P<0.10$ & malam terhadap pagi $(\mathrm{P}<0,033)$ \\
\hline \multirow{4}{*}{ SOF } & Sleepiness & $P<0.10$ & malam terhadap pagi $(P<0,033)$ \& malam terhadap siang $(\mathrm{P}<0,033)$. Malam ${ }^{*}$ \\
\cline { 2 - 4 } & Physical Discomfort & $P<0.10$ & malam terhadap pagi $(\mathrm{P}<0,033)$ \\
\cline { 2 - 4 } & Lack of Motivation & $P<0.10$ & tidak ada perbedaan yang signifikan \\
\cline { 2 - 4 } & Lack of Energy & $P>0.10$ & - \\
\cline { 2 - 4 } & Physical Exertion & $P>0.10$ & - \\
\hline
\end{tabular}

Keterangan *) Shift tersebut sangat signifikan mempengaruhi jika dibandingkan kedua shift lainnya

Berdasarkan hasil pengukuran SOFI, Pada umumnya tingkat kantuk meningkat saat shift malam. Peningkatan tingkat kantuk berkisar antara $73 \%$ hingga $162 \%$ jika dibandingkan dengan shift pagi dan siang. Tingkat kantuk terendah terjadi saat shift siang yang berarti dapat dikatakan bahwa saat shift siang lah operator merasa sangat terjaga. Tingkat ketidaknyamanan fisik (physical discomfort) tertinggi terjadi saat malam hari. Peningkatan rasa ketidaknyamanan fisik (physical discomfort) berkisar antara 101\% - 140\%. Penurunan motivasi menunjukkan adanya perbedaan yang signfikan antar shift namun saat diuji lebih lanjut dengan uji BonferonniDunn Post Hoc hasil tidak menunjukkan shift mana yang paling signifikan berbeda. Hal ini dapat disebabkan karena jumlah sampel partisipan yang kecil. Meskipun begitu, hasil uji Friedman yang menunjukkan signifikan tetap valid. Data menunjukkan bahwa adanya penurunan motivasi saat shift siang dan malam sebesar $42 \%-51 \%$ jika dibandingkan shift pagi.

Hasil pengukuran waktu reaksi menunjukkan shift malam menghasilkan waktu reaksi terlama. Meskipun parameter mean 1/RT terbukti tidak signifikan berbeda antar shift, namun shift malam menghasilkan waktu reaksi lebih lambat sekitar 5\%-9\% jika dibandingkan dengan shift pagi dan siang. Parameter fastest 10\% 1/RT menunjukkan saat shift malam waktu reaksi lebih lambat sekitar $3 \%-6 \%$ jika dibandingkan shift pagi dan siang, sedangkan parameter slowest 1/RT menunjukkan bahwa saat shift malam lebih lambat sekitar 5\%-11\%. Jika dilihat berdasarkan parameter number of lapses, saat shift malam mengalami peningkatan $25 \%-70 \%$.

Pengukuran SOFI menunjukkan bahwa shift kerja signifikan mempengaruhi kelelahan dalam hal kantuk (sleepiness), ketidaknyamanan fisik (physical discomfort) dan penurunan motivasi (lack of motivation). Hasil pengukuran sedikit berbeda dengan hasil penelitian Ashberg (1988) yang mendeskripsikan bahwa shift kerja secara kuat mempengaruhi tingkat kantuk (sleepiness), penurunan motivasi (lack of motivation) dan penurunan energi (lack of energy). Pada penelitian ini, petugas pengendali merasakan bahwa energi yang dihabiskan pada setiap shift tidak berbeda. Dengan kata lain, petugas pengendali merasakan bahwa beban pekerjaan setiap shift tidak berbeda.

Tidak adanya penurunan energi (lack of energy) yang berbeda dalam setiap shift dapat disebabkan kondisi kerja. Saat shift malam, waktu kerja dimulai sejak pukul 20.00-08.00, yaitu 12 jam. Jam kerja shift malam lebih panjang dari shift pagi dan siang yang hanya 6 jam masing-masing. Namun saat shift malam terdapat waktu kosong dari pukul 00.02-03.12, kurang lebih 3 jam, yang dapat digunakan oleh para karyawan untuk beristirahat. Meskipun pada kenyataannya, saat penelitian dilakukan, 
tidak semua petugas pengendali menggunakan waktu tersebut untuk beristirahat, dengan alasan menonton acara televisi atau merasa tanggung untuk tidur hanya 3 jam. Selain itu, pekerjaan awak darat operasional merupakan pekerjaan yang tidak membutuhkan banyak aktivitas bergerak, hanya duduk, namun membutuhkan ketelitian dan kewaspadaan yang sangat tinggi, sehingga kemungkinan timbulnya perasaan lesu, lunglai atau kehabisan energi tidak terlalu tinggi. Situasi dan kondisi lainnya, seperti ketersediaan makanan pun, dapat berpengaruh. Meskipun lokasi divisi pengendali jauh dari pusat stasiun dan pusat makanan, namun terdapat petugas khusus, khususnya pada malam hari, yang menyediakan makanan dan minuman bagi para petugas pengendali.

Ashberg (1998) mendeskripsikan bahwa ketidaknyaman fisik (physical discomfort) dapat disebabkan karena pekerjaan statis. Petugas pengendali bekerja dengan tipe pekerjaan statis, dimana mereka bekerja dengan duduk di atas kursi menghadap meja dan panel-panel atau komputer untuk mengontrol perjalanan kereta api. Tidak dibutuhkan suatu kondisi yang mewajibkan banyaknya pergerakan tubuh. Pada penelitian ini ketidaknyaman fisik (physical discomfort) lebih terasa saat shift malam. Hal ini sejalan dengan penelitian sebelumnya oleh Basner dkk., (2008) dan Costa (1996) dalam Rameshbabu (2012).

Ashberg (1988) mendeskrisikan bahwa penurunan motivasi (lack of motivation) dapat disebabkan tuntutan kerja mental. Pekerjaan pengendali membutuhkan konsentrasi, ketelitan dan kewaspadaan yang tinggi dengan risiko jika terjadi kesalahan maka berkaitan dengan keselamatan kereta api. Tipe pekerjaan tersebut merupakan tipe pekerjaan mental. Kandel dkk., (2000) dalam Leung, Chan \& He (2004) pun mendeskripsikan bahwa kelelahan mental dapat mengakibatkan timbulnya rasa kantuk dan penurunan motivasi.

Meskipun dimensi kantuk (sleepiness), penurunan motivasi (lack of motivation) dan ketidaknyaman fisik (physical discomfort) terbukti signifikan berbeda, namun sebagian besar skala yang dihasilkan dibawah skala 1 . Hal ini menunjukkan bahwa meskipun ketiga dimensi tersebut signifikan dipengaruhi oleh shift kerja, namun dampaknya tidak terlalu berarti, para pengendali masih dapat bekerja dengan baik. Jika dilihat pada Gambar 1 terdapat beberapa hasil pengukuran yang menghasilkan nilai SOFI paling tinggi jika dibandingkan nilai lainnya dimana nilai tertinggi di sekitar skala 4, sedangkan sebagian besar hasil pengukuran berada di skala 3 ke bawah. Hal ini menunjukkan bahwa implikasi operasional tidak terlalu berdampak kepada tingkat kelelehan, namun faktor individu dalam penelitian ini memungkinkan dalam mempengaruhi hasil.

Hasil pengukuran waktu reaksi sedikit berbeda dibandingkan hasil pengukuran SOFI. Berdasarkan pengukuran SOFI dimensi kantuk (sleepiness) menunjukkan bahwa saat shift siang pengendali merasa sangat terjaga dan paling waspada, sedangkan pengukuran waktu reaksi menunjukkan bahwa pengendali paling waspada saat shift pagi. Hal ini dapat diakibatkan oleh faktor irama sirkadian manusia. Menurut irama sirkadian, mulai pukul 6 pagi suhu tubuh manusia akan meningkat dan puncaknya adalah pukul 7 malam. Hormon melatonin yang berpengaruh pada timbulnya kantuk pada manusia pun terhenti pada pukul 07.30 pagi. Kenneth dkk., (2002) dalam Amin (2006) mendeskripsikan bahwa adanya hubungan antara suhu tubuh dengan performansi manusia. Kenaikan suhu tubuh mempengaruhi fungsi kognitif yang melibatkan performansi seperti ingatan, kewaspadaan dan perhatian visual.

Berdasarkan data waktu reaksi untuk keempat parameter menunjukkan bahwa shift malam yang menghasilan performansi terendah. Hal ini sesuai dengan penelitian sebelumnya (Kazemi, Haidarimoghadam, Motamedzadeh, Golmohamadi, Soltanian \& Zoghipaydar, 2016) yang mendeskripsikan bahwa performansi, khususnya performansi kognitif, menurun setelah shift malam. Namun, dari keempat parameter tersebut, perbedaan antar shift yang sangat mencolok adalah number of lapses. Number of lapses menunjukkan bahwa partisipan merespon stimulus $\geq 500 \mathrm{~ms}$, dimana hal tersebut menunjukkan adanya kesalahan yang diakibatkan oleh kelalaian atau penurunan kewaspadaan (Basner, Mollicone \& Dinges, 2011). Berdasarkan pengolahan data bahwa peningkatan number of lapses di pada malam hari adalah yang tertinggi dibandingkan parameter lainnya, yaitu mencapai $70 \%$ jika dibandingkan kedua shift lainnya. Hal ini 
menunjukkan bahwa performansi terburuk terjadi saat shift malam.

Secara keseluruhan, tingkat kelelahan setelah shift malam meningkat sekitar 37\% hingga $162 \%$ dan tingkat performansi setelah shift malam menurun sekitar $3 \%$ hingga $11 \%$ jika dibandingkan shift pagi dan siang. Hal ini sedikit berbeda dengan hasil penelitian Harma, Saliinen, Ranta, Mutanen \& Muller (2002) bahwa kelelahan dan kantuk tidak hanya terjadi saat shift malam, namun juga shift pagi.

Jika dilihat dari pola shift kerja serta waktu istirahat, sebagian besar perusahaan telah menetapkan sistem sesuai yang disarankan pada penelitian sebelumnya (Hesselink, 2010 ; Bridger, 2009; Health and Safety Executive, 2006 ; Knauth \& Hornberger, 2003). Penelitian sebelumnya mendeskripsikan bahwa pola shift sebaiknya tidak permanen, menggunakan sistem fast rotation, mengadaptasi sistem forward. Hindari durasi jam kerja lebih dari 8 jam, waktu istirahat antar shift yang berbeda minimal 11 jam, setelah shfit malam sebaiknya mendapatkan libur kerja. Selain itu diharapkan untuk menghindari hari kerja saat weekend karena akan menimbulkan stres sosial. Hindari menetapkan waktu mulai kerja dibawah jam 7 pagi untuk shift pagi. PT.KAl telah menetapkan sistem forward dengan fast rotation, yaitu 2-21-2 (2 hari shift pagi- 2 hari shift siang-1 hari shift malam-2 hari libur). Shift pagi dimulai pukul 08.00 dan waktu istirahat antar shift yang sama 16 jam serta antar shift berbeda hampir 24 jam.

Terdapat sedikit permasalahan mengenai jam kerja. Jam kerja masing-masing antar shift berbeda dimana shift pagi 6 jam shift siang 6 jam, dan shift malam 12 jam. Narciso, Barela, Aguiar, Carvalho \& Tufik (2016) mendeskrispikan bahwa pekerja malam dengan durasi kerja 12 jam berdampak pada penurunan performansi. Shift malam mengalami jam kerja terlama disebabkan adanya adanya selang 3 jam tanpa pekerjaan apapun, yaitu jam 12 malam hingga 3 subuh, karena tidak ada perjalanan kereta api. Shift pagi dan siang adalah saat dimana jadwal kereta terpadat. Rata-rata waktu selang antar kereta (baik datang maupun berangkat) untuk shift pagi adalah 11 menit, shift siang 12 menit dan shift malam 18 menit. Namun, apabila dikurangi dengan waktu istirahat tersebut, karyawan tetap bekerja selama 9 jam, melebihi waktu kerja yang disarankan. Rosa dan Bennert dalam Bridger (2009) mendeskripsikan bahwa bekerja lebih dari 8 jam dapat meningkatkan risiko kesalahan dan kecelakaan kerja. Menurut Safety and health Executive (2006) untuk pekerjaan monoton, membutuhkan konsentrasi dan ketelitian tinggi, terisolasi dan penuh waspada diharapkan tidak bekerja lebih dari 8 jam.

Menyamakan jam kerja antara shift pagi, siang dan malam menjadi 7 jam masingmasing dapat menjadi pertimbangan bagi perusahaan. Jika shift pagi dan siang lebih banyak jam kerjanya, meskipun masih dalam batas yang disarankan, dikhawatirkan akan berdampak pada shift pagi dan siang yang menjadi puncak kelelahan dan performansi terburuk. Selain itu, jika jam kerja kedua shift tersebut lebih panjang dari 7 jam, terdapat kemungkinan shift siang akan selesai lebih dari pukul 22.00. Knauth dan Hornberger (2003) mendeskripsikan bahwa waktu selesai shift kerja akan lebih baik tidak melebihi pukul 22.00, hal tersebut dilakukan untuk meminimisasi tingkat kantuk yang terjadi dan memungkinkan agar manusia masih dapat bersosialisasi.

Terdapat beberapa faktor lain yang dapat mempengaruhi hasil pengukuran. Faktor lain seperti kepribadian (Bridger, 2008), status menikah ataupun jumlah anak (Baker dkk., 2004 dalam Ryan dkk, 2008) mungkin saja mempengaruhi tingkat kelelahan dan performansi para pengendali. Begitu juga dengan usia. Harma dkk., (2002) mengklasifikasikam usia menjadi dua bagian yaitu di bawah 43 tahun (muda) dan 43 tahun ke atas (tua). Pada penelitian in, hampir $82 \%$ usia partisipan di bawah 43 tahun. Harma dkk., (2002) mendeskripsikan bahwa pada masinis, golongan muda lebih berisiko mengalami kantuk dibandingkan yang lebih tua. Rata-rata pengalaman bekerja para pengendali adalah $9,06 \pm 8$ bulan. Pengalaman kerja dapat menjadi faktor yang mempengaruhi namun faktor-faktor tersebut tidak dibahas lebih dalam pada penelitian ini

Hasil penelitian ini diperoleh berdasarkan partisipan pria, akan ada kemungkinan hasil penelitian berbeda jika diterapkan pada wanita. Blatter, Graw, Munch, Knoblauch, Justice \& Cajochen, (2006) mendeskrispikan bahwa wanita menghasilkan waktu reaksi yang lebih lambat jika dibandingkan dengan pria. Baldwin, Kapur, holberg, Rosen \& Nieto (2004) mendeskripsikan bahwa wanita lebih banyak mengeluhkan kurang tidur, susah tidur, susah 
bangun pagi atau mengalami tidur yang berkualitas. Kroenke dan Spitzer (1998) dalam Baldwin, Kapur, holberg, Rosen \& Nieto (2004) mendeskripsikan bahwa wanita lebiih banyak melaporkan perasaan lelah dan insomnia jika dibandingkan pria. Tidak menutup kemungkinan bahwa perbedaan jenis kelamin menghasilkan perbedaan pada hasil pengukuran (Park, 2007)

\section{Kesimpulan dan Saran}

Shift kerja mempengaruhi tingkat kelelahan dan performansi. Shift kerja mempengaruhi kelelahan khususnya kantuk, ketidaknyaman pada fisik tubuh dan penurunan motivasi manusia. Penelitian ini menunjukkan bahwa manusia merasa paling terjaga saat shift pagi dan siang. Performansi terbaik terjadi saat shift pagi. Tingkat kelelahan dan performansi terburuk terjadi saat shift malam.

Tiga dari empat parameter waktu reaksi menunjukkan bahwa adanya perbedaan signifikan antar shift kerja. Keempat parameter waktu reaksi menunjukkan bahwa performansi terbaik terjadi saat shift pagi dan terburuk terjadi saat shift malam. Tiga dari lima dimensi SOFI menunjukkan adanya perbedaan yang signifikan antar shift kerja. Hasil uji statistik menunjukkan bahwa shift malam yang paling mempengaruhi. Berdasarkan data, umumnya kelelahan tertinggi terjadi saat shift malam. Namun, dimensi penurunan motivasi dan ketidaknyamana fisik keseluruhan antara shift siang dan malam tidak terlalu berbeda.

Hal yang menarik pada penelitian ini adalah meskipun ada perbedaan signifikan untuk beberapa dimensi SOFI, namun nilai yang dihasilkan rata-rata skala tertinggi adalah 1 (dari skala 0-7). Hal tersebut menunjukkan bahwa meskipun terbukti secara signifikan bahwa shift kerja mempengaruhi tingkat kelelahan, namun kelelahan yang dirasakan sangat rendah. Dapat dikatakan bahwa dampak kelelahan yang dirasa tidak terlalu berarti.

Pada penelitian ini, usulan yang diberikan adalah menyamaratakan jam kerja untuk ketiga shift, tidak berusaha agar jam kerja shift malam lebih singkat dari shift lainnya, yaitu 7 jam kerja masing-masing. Pengolahan data pada penelitian dilakukan dengan menghitung ratarata, sehingga beberapa partisipan yang memiliki nilai tinggi pada masing-masing pengukuran tertutup oleh hasil pengukuran partisipan lain, oleh karena itu akan untuk penelitian selanjutnya sebaiknnya dilihat berdasarkan tingkat individu masing-masing. Faktor-faktor individu ini layak menjadi perhatian pihak PT.KAI . Kepribadian, status menikah, jumlah anak, umur maupun pengalaman kerja dapat mempengaruhi hasil pengukuran namun pada penelitian ini tidak dibahas lebih dalam.

Kuesioner SOFI merupakan kuesioner yang telah terbukti valid dalam. Namun validasi ke dalam bahasa Indonesia pada saat penelitian ini dilakukan belum ada. Pada penelitian ini, SOFI diterjemahkan dengan bantuan ahli bahasa dari Institut Teknologi Bandung. Penerjemahan hanya dilakukan satu tahap yaitu ke dalam bahasa Indonesia, tidak dilakukan penerjemahan kembali ke dalam bahasa Inggris. Pada penelitian selanjutnya sebaiknya penerjemahan SOFI dilakukan dua arah.

Pada hasil uji statistika terdapat dua parameter dimana uji Friedman menunjukan adanya perbedaan yang signifikan antar shift kerja namun saat uji Bonferonni-Dunn Post Hoc tidak terbukti signifikan. Hal ini dapat disebabkan karena jumlah sampel yang kecil yang menjadi pertimbangan penggunaan non parametrik. Untuk penelitian selanjutnya sebaiknya menggunakan jumlah sampel yang besar serta uji statistika parametrik dan uji Post Hoc lain untuk lebih menguatkan hasil penelitian

\section{Daftar Pustaka}

Amin, M.M. (2006). Influence of Circadian Rhythm on The Physical and Mental Perfomance. Thesis. Louisiana State University, Lousiana

Ashberg, E. (1998). Perceived Fatigue Related to Work. ISBN 91-7135-830-5.

Ashberg, E. (2000). Dimension Of Fatigue In Different Working Populations. Scandinavian Journal of Psychology, Vol (41), 231-241.

Baldwin, C. M., Kapur, V. K., Holberg, C. J., Rosen, C., dan Nieto, F. J. (2004). Associations Between Gender and Measures of Daytime Somnolance in the Sleep Heart Health Study. Sleep, Vol.27 (2).

Basner, M., Mollicone, D., dan Dinges, D. F. (2011). Validity And Senstivity Of A Brief Psychomotor Vigilance Test (Pvt-B) To Total And Partial Sleep Deprivation. Acta Austronatica, Vol. (69), 949-959 
Basner, M.,dan Dinges, D.F. (2011). Maximizing Sensitivity Of The Psychomotor Vigilance Test (PVT) to Sleep Loss. University of Pennsylania School of Medicine, Vol. 34 (5)

Blatter, K., Graw, P., Munch, M., Knoblauch, V., Justice, A.W. dan Cajochen, C. (2006). Gender And Age Differences In Psychomotor Vigilance Performance Under Differential Sleep Pressure Condition. Behaviourial Brain Research, Vol.168, 312317

Barbey, A., Reeves, G., Arnulf, I., Holmes, A. (2007). Managing Fatigue in the Workplace: A Guide For Oil and Gas Industry Supervisors and Occupational Health Practitioners. London, UK : IPIECA and OGP.

Bridger, R.S. (2008). Introduction to Ergonomics ( $3^{\text {rd }}$ ed.). London, UK : Taylor dan Francis Group.

Cotrim, T., Carvalhais, J., Neto, C., Teles, J., Noriega P. dan Rebelo, F. (2017). Determinants Of Sleepiness At Work Among Raikway Control Workers. Applied Ergonomics, 293-300

Coffey, L.C., Skipper Jr, J.K., Jung R.N, F.D. (2006). Nurses And Shift Work : Effects On Job Performance And Job-Related Stress, Journal of Advanced Nursing, Vol.13 (2), 245-254.

Demsar, J. (2006). Statistical Comparisons Of Classifiers Over Multiple Data Sets. Journal of Machine Learning Research, Vol.7, 1-30.

Dorrian, J., Baulk. S. D., dan Dawson, D. (2011). Work Hours, Workload, Sleep And Fatigue In Australian Rail Industry Employees. Applied Ergonomics, Vol.42, 202-209.

Elfering,A., Grebner,S., dan Haller, M. (2012). Railway-Controller-Perceived Mental Workload, Cognitive Failure And Risky Commuting, Ergonomics, Vol, 55 (12),. 1463-1475

Gawron, V.J. (2008). Human Performance, Workload and Situasional Awareness Measures Handbook, $2^{\text {nd }}$ edition. CRC Press, Taylor \& Francis Group, Boca Raton.

Gerber, M., Hartmann, T., Brand, S., Trachsler, E. D., dan Puhse, U. (2010). The relationship between shift work, perceived stress, sleep and health in swiss police officers. Journal of Criminal Justice, 38, 1167-1175.
Goswani, R., Jena. R. K., dan Mohapatra, B. B. (2012). Effect Of Shift Work On Health: A Review. International Journal Research in Management, Vol.3 (2), 2249-5908.

Grandjean, E. P., Wotzka, G., Schaad, R., dan Gilgen. A. (2007). Fatigue And Stress In Air Traffic Controller. Ergonomics, Vol.14 (1), 159-165.

Graw, P., Krauchi, K., Knoblauch, V., WirzJustice, A., dan Cajochen, C. (2004). Circadian And Wake-Dependent Modulation Of Fastetst And Slowest Reaction Times During The Psychomotro Vigilance Task. Physiology \& Behaviour, Vol. 80, 695-701

Gunzelmnaa, G., Gross, J.B., Gluck, K.A., dan Dinges, D.F. (2009). Sleep Deprivation And Sustained Attention Performance : Integrating Mathematical And Cognitive Modelling. Cognitive Science, Vol.33, 880910.

Harma,M., Sallinen, M., Ranta, R., Mutanen, P., dan Muller, K.(2002). The Effect Of An Irregular Shift System On Sleepiness At Work In Train Drivers And Railway Traffic Controller. J. Sleep Res, Vol.11, 141-151. [Wilet Online Library].

Health dan Safety Executive. (2006). Managing Shiftwork, Health and Safety Guidance. [Online Book].

Hesselink, J. K., Leede, J.D., dan Goudswaard, A. (2010). Effect Of The New Fast Forward Rotating Five-Shift Roster At A Dutch Steel Company.Ergonomics, Vol.53 (6), 727-738.

Irianti, L., Geovania, A., dan Iridiastadi, H. (2015). Pengaruh Shift Kerja Terhadap Stres Kerja Pengendali (Controller) Kereta Api Indonesia. Jurnal Rekayasa Sistem dan Industri, Vol.2(4), 39-45

Jackson, M.L., Croft, R.J., Kennedy, G.A., Owens, K., dan Howard, M.E. (2013). Cognitive Component Of Simulated Driving Performance : Sleep Loss Effects And Predictors. Accident Analysis and Prevention, Vol.50, 438- 444.

Jay, S. M., Dawson, D., Ferguson, S. A., dan Lamond, D. (2008). Driver Fatigue Extended Rail Operations. Applied Ergonomics, Vol.39, 623-620.

Johansson. S., Ytterberg, C., Back, B., Holmqvist, L.W., dan Koch, L. V. (2008). The Swedish Occupational Fatigue Inventory In People With Multiple Sclerosis. J Rehabil Med, Vol.40, 737-743. 
Johns, M. W. (2009). What Is Excessive Daytime Sleepiness?. In Sleep Deprivation: Causes, Effects And Treatment. Australia : Nova Science Publishers, Inc.

Kaida, K., Takahashi, M., Akestedt, T., Nakata, A., Otsuka, T., Haratani, T., dan Fukasawa, K. (2006). Validation Of Karolinska Sleepness Scale Against Performance And EEG Variables. Clinical Neurophysiology, Vol.117, 1574-1581.

Kazemi, R., Haidarimoghadam, R., Motamedzadeh, M, Golmohamadi, R., Soltanian, A., dan Zoghipaydar, M.R. (2016). Effects Of Shift Work On Cognitive Performance, Sleep Quality, And Sleepiness Among Petrochemical Control Room Operator. Journal of Circadian Rhythms , Vol.14 (1), 1-5

Kementerian Perhubungan. Statistik Perhubungan, [Online], Diakses pada 23 Maret 2017, dari http://dephub.go.id.

Knauth, P.,dan Hornberger, S. (2003). Preventive And Compensatory Measures For Shift Workers. Occupational Medicine, Vol.I (53), 109-116.

Leung, A.W.S., Chan,C. C. G., dan He, J.(2004). Structural Stability And Reliability Of Swedish Occupational Fatigue Inventory Among Chinese Vdt Workers. Applied Ergonomics, Vol. 35, 233-241.

Loh, S., Lamond, N., Dorrian, J., Roach, G., dan Dawsn, D. (2004). The Validity Of Physchomotor Vigilance Tasks Of Less Than 10 Minutes Duration. Behaviour Research Methods, Instruments and Computers, Vol. 36 (2), 339-346.

Muhammad, I. (2009). Hubungan Antara Shift, Umur, dan Masa Kerja dengan Stres Kerja Pada Penjaga Jalan Perlintasan Kereta Api di Yogyakarta. (Tesis, Universitas Gadjah Mada, 2009) diakses dari http://etd.repository.ugm.ac.id/index.php?m od=penelitian_detail\&sub=PenelitianDetail\& act=view\&typ=html\&buku_id=42595

Narciso, F.V., Barela, J.A., Aguiar, S.A., Carvalho, A.N.A., Tufik, S., dan de Mello, M.T. (2016). Effects Of Shift Work On The Postural And Psychomotor Performance Of Night Workers.Plos ONE, Vol. 11 (4), e0151609

Newson, J.(2006). Post Hoc Tests. Portland State University.

Nurussakinah, A., Puspitasari, N.B. \& Rumita R. (2014). Pengaruh Beban Kerja Mental dan
Kelelahan Kerja Terhadap Kesalaha Operator Pengendali Kereta DAOP IV Semarang. Industrial Engineering Online Jurnal, Vol. 3 (1).

Ozdemir P.G., Selvi Y., Ozkol H., Aydin A., dan Tuluce Y. (2013). The Influence Of Shift Work On Cognitive Fuctions And Oxidative Stress. Psychiatry Research,Vol. 210, 12191225.

Park, J.(2007). Work Stress And Job Performance. [Katalog], 75-001-XIE. Kanada.

Pratiwi, C.F. (2016). Hubungan Shift Kerja dengan Kelelahan Kerja Pada Pekerja Bagian Daily Check di PT. Kereta Api Daerah Operasi VI Yogyakarta DIPO Kereta Solo Balapan. (Tugas Akhir, Universitas Muhammadiyah Surakarta, 2016). Diakses dari

http://eprints.ums.ac.id/48792/33/NASKAH \%20PUBLIKASI.pdf.

Rameshbabu, A., Reddy, D. M., dan Fleming, R.(2012). Correlates Of Negative Physical Health In Call Center Shift Workers. Applied Ergonomics, Vol.44, 350-354.

Ryan, B., Wilson, J. R., Sharples, S., Kenvyn, F., dan Clarke, T.(2008). Rail Signallers Assessment Of Their Satisfaction With Different Shift Work System. Ergonomics, Vol.51 (11), 1656-1671.

Stoohs, R.A., Phillip, P., Andries, D., Finlayson, E.V., dan Guilleminault, C.(2009).Reaction Times Performance In Upper Airway Resistance Syndrome Versus Obstructive Sleep Apnea Syndrome. Sleep Medicine, Vol. 10, 1000-1004.

Titova, O.E., Lindberg, E., Elmstahl, S., Lind, L., Schioth, H.B., dan Benedict, C. (2016). Association Between Shift Work History And Performance On The Trail Making Test Ini Middle-Aged And Elderly Humans : The Epihealth Study. Neurobiology of Aging.

Tucker, A.M., Whitney, P., Balenky, G., Hinson, J.M., dan Van Dongen H.P. (2010). Effects of Sleep Deprivation on Dissociated Components of Executive Functioning. Sleep, Vol. 33 (1), 47-57.

Ummul, S.,dan Kameswara, R. K. (2012). Shift Work And Fatigue. IOSR Journal Of Environmental Science, Toxicology and Food Technology(IOSR-JESTFT), Vol.1 (3)

Williamson, A., Lombardi, D. A., Folkard, S., Stutts, J., Courtney, T.K., dan Connor, J.L. (2009). The Link Between Fatigue And 
Safety: Accidents Analysis And Prevention. Accident Analysis \& Prevention, Vol.43 (2), 498-515.

Wilkinson, R., Allison, S., Feeney, M., dan Zaminska, Z. (2007). Alertness Of Night Nurses: Two Shift Systems Compared. Ergonomics, Vol. 32 (3), 281-292.

Yogi, J dan Hirkarni, M. (2016). Effect of Sleep Deprivation on Audio-Visual Reaction Time in Resident Doctors- a Measure of Task Performance. Indian Journal of Basic and Applied Medical Research, Vol. 5 (2), 29-35 
Halaman ini sengaja dikosongkan

This page is intentionally left blank 